\title{
PENINGKATAN KADAR ASAM LAKTAT DALAM DARAH SESUDAH BEKERJA
}

\section{THE INCREASED OF LACTIC ACID CONCENTRATION IN THE BLOOD AFTER WORK}

\author{
Irma Hidayah \\ Persatuan Sarjana Kesehatan Masyarakat Indonesia, Kota Surabaya \\ E-mail: irmahidayah.37@gmail.com
}

\begin{abstract}
Fatigue is a protective mechanism of the body to avoid further damage resulting in the recovery after the break. It can occur because of a accumulation of lactic acid due to continuous muscle contraction. One of the jobs in Gunawangsa Tidar Superblock Apartment Project at PT. PP (Persero) Tbk. which can lead to fatigue is formwork jobs. The purpose of the study was to analyze the increased concentration of lactic acid in the blood after work on the formwork workers Gunawangsa Tidar Superblock Apartment Project at PT. PP (Persero) Tbk. This study was an observational study with cross-sectional study design. Data obtained by using interviews with questionnaires about sexs, ages, length of work, duration of work, duration of rest, work day and perception of heat exposure. Beside that, data wa collected by measuring lactic acid consentration in the blood with the Accutrend Plus Brand Roche to 30 formwork workers. The independent variable was working while dependent variable was concentration of lactic acid in the blood. Data were tested using Wilcoxon Signed Ranks Test. The results showed that the average concentration of lactic acid in the blood before and after work, namely $0.263 \mathrm{mmol} / \mathrm{l}$ and $0.883 \mathrm{mmol} / \mathrm{l}$. Based on statistical test of Wilcoxon Signed Ranks Test, was obtained $N$ Positive Ranks $=16$ with Asymp. Sig. (2-tailed) $=0.001$. The conclusion of this study that there is an increase in lactic acid consentration in the blood after work.
\end{abstract}

Keywords: blood, fatigue, lactic acid

\begin{abstract}
ABSTRAK
Kelelahan kerja adalah suatu mekanisme perlindungan tubuh untuk menghindari kerusakan lebih lanjut sehingga terjadi pemulihan setelah istirahat. Hal ini dapat terjadi karena penumpukan asam laktat akibat kontraksi otot secara terus menerus. Salah satu pekerjaan di Proyek Apartemen Gunawangsa Tidar Superblock di PT. PP (Persero) Tbk. yang dapat menyebabkan kelelahan adalah pekerjaan bekisting. Penelitian ini bertujuan untuk menganalisis peningkatan kadar asam laktat dalam darah sesudah bekerja pada pekerja bekisting Proyek Apartemen Gunawangsa Tidar Superblock di PT. PP (Persero) Tbk. Penelitian ini adalah penelitian observasional dengan desain penelitian cross-sectional study. Data diperoleh dengan menggunakan wawancara dengan kuesioner mengenai jenis kelamin, umur, masa kerja, lama waktu kerja, lama waktu istirahat, hari kerja, dan persepsi ada tidaknya paparan panas. Pengambilan data juga dilakukan dengan pengukuran kadar asam laktat dalam darah dengan Accutrend Plus Merk Roche terhadap 30 pekerja bekisting. Dalam penelitian ini variabel bebas adalah bekerja sedangkan variabel terikat adalah kadar asam laktat dalam darah. Data diuji dengan menggunakan Wilcoxon Signed Ranks Test. Hasil penelitian menunjukkan bahwa rata-rata kadar asam laktat dalam darah responden sebelum dan sesudah bekerja yaitu $0,263 \mathrm{mmol} / \mathrm{l}$ dan $0,883 \mathrm{mmol} / \mathrm{l}$. Uji statistic Wilcoxon Signed Ranks Test yang dilakukan menunjukkan perolehan N Positive Ranks $=16$ dengan Asymp. Sig. (2-tailed) $=0,001$. Kesimpulan dalam penelitian ini adalah terdapat peningkatan kadar asam laktat dalam darah sesudah bekerja.
\end{abstract}

Kata kunci: asam laktat, darah, kelelahan

\section{PENDAHULUAN}

Bekerja merupakan salah satu aktivitas yang dilakukan oleh manusia. Tujuan manusia bekerja yaitu untuk mempertahankan hidup dan kehidupannya. Selain itu, seseorang bekerja karena ada sesuatu yang ingin dicapai dan berharap aktivitas kerja tersebut dapat mengubah keadaannya menjadi lebih baik dari sebelumnya (Susetyo, et al., 2012).

Selama melakukan pekerjaannya, tubuh manusia menerima rangsangan yang menyebabkan otot berkontraksi secara terus menerus sehingga suplai oksigen ke otot akan berkurang. Kondisi ini mengakibatkan terjadinya pergeseran sumber energi 
aktivitas otot yang semula berasal dari asam lemak ketika suplai oksigen cukup, kemudian beralih ke sumber energi lain yang proses perombakannya tidak memerlukan oksigen (Murray, 2005).

Matthew (2003) menyebutkan bahwa otot dapat tetap beraktivitas saat suplai oksigen berkurang dengan menggunakan Adenosine Triphosphat (ATP) dan Ceratine Phosphate (CP) sebagai sumber energi. Ketersediaan kedua senyawa tersebut di sel otot sangat terbatas sehingga hanya mampu mencukupi energi untuk aktivitas otot yang sesaat dan tiba-tiba yang membutuhkan daya ledak otot yang tinggi. Ketika otot beraktivitas secara kontinyu saat ketersediaan oksigen tidak cukup, maka dapat digunakan sumber energi lain berupa karbohidrat yaitu glukosa.

Semua karbohidrat yang masuk ke dalam tubuh akan dikonversi menjadi glukosa yang kemudian disimpan dalam hati dan otot sebagai glikogen untuk cadangan energi (Lamb, 1984, Fox et al., 1993). Glikogenakan diubah menjadi asam piruvat melalui reaksi glikolisis anaerobik (Ardle et al., 1981).

Glikolisis anaerobik adalah serangkaian reaksi kimia yang menghasilkan energi tanpa melibatkan oksigen dalam reaksi kimianya. Glikolisis anaerobik akan melepaskan energi dari molekul glikogen. Energi yang dihasilkan digunakan untuk membentuk kembali ADP dan Pi menjadi ATP, dan energi yang dihasilkan dari ATP ini dapat digunakan otot untuk beraktivitas fisik (Pateet al., 1984, Foxet al., 1993).

Murray (2005) menjelaskan bahwa reaksi glikolisis berlangsung di sitosol sel otot dalam keadaan anaerob (tanpa oksigen). Glikolisis anaerobik sangat bermanfaat dalam penyediaan energi dalam waktu yang relatif cepat dan tanpa menggunakan oksigen. Namun, glikolisis anaerobik juga memiliki kelemahan, yaitu menghasilkan suatu produk akhir berupa asam laktat yang sangat merugikan karena dapat menyebabkan kelelahan kerja otot.

Weihrer (1991) menjelaskan bahwa asam laktat adalah biomolekul tiga karbon dengan gugus karboksil dan gugus hidroksil. Asam laktat merupakan asam yang cukup kuat. Farenia et al. (2010) memaparkan bahwa asam laktat adalah produk akhir dari proses glikolisis anaerob yang dihasilkan oleh sel darah merah dan sel otot yang aktif. Dalam keadaan istirahat, asam laktat dihasilkan oleh sel darah merah, sel darah putih, otak, sel otot, sel hepar, mukosa usus, dan kulit.

Ardle et al. (1981) dan Fox et al. (1993) berpendapat bahwa asam laktat yang terbentuk dari glikolisis anaerobik akan menurunkan $\mathrm{pH}$ sehingga suasana otot berubah menjadi asam. Keadaan ini dapat meningkatkan keasaman darah apabila berlangsung lama. Perubahan $\mathrm{pH}$ dalam otot yang menjadi asam ini akan menghambat kerja enzimenzim glikolisis sehingga akan mengganggu reaksi kimia yang berlangsung di dalam sel. Hal ini akan mengakibatkan berkurangnya energi yang dihasilkan sehingga kontraksi otot semakin lemah dan pada akhirnya otot akan mengalami kelelahan.

Beberapa ahli juga mengemukakan teori yang sama. Saltin and Edstrom (1981) mengemukakan bahwa akumulasi asam laktat dalam otot akan menurunkan kemampuan otot untuk bekerja. Janssen (1987) juga mengemukakan bahwa selain dapat menyebabkan asidosis pada sel otot dan terganggunya koordinasi otot, peningkatan kadar asam laktat yang cukup tinggi juga dapat meningkatkan risiko cedera serta mengganggu sistem fosfokreatin dan oksidasi asam lemak. Selain itu, penumpukan asam laktat pada tendon otot seringkali mengakibatkan rasa pegal atau nyeri setelah melakukan pekerjaan (Peterson, 2006).

Reduksi piruvat menjadi asam laktat adalah reaksi akhir dari glikolisis dan reaksi ini biasa disebut sebagai "jalan buntu" yang berarti bahwa asam laktat tidak dapat dikatabolis lebih lanjut. Setelah diproduksi asam laktat dapat meninggalkan sel, menumpuk di dalam sel, atau dioksidasi kembali ke piruvat karena enzim Laktat Dehidrogenase (LDH) bersifat reversible (Weihrer, 1991). Asam laktat ini akan menunggu keadaan otot menjadi aerob untuk diubah lagi menjadi asam piruvat oleh sel di jaringan otot atau di limpa dan hati (Peterson, 2006).

Ningrum (2012) menyatakan bahwa kelelahan timbul karena penumpukan asam laktat dalam jaringan. Hal ini disebabkan oleh kemampuan tubuh menetralisir tumpukan asam laktat tersebut tidak sebanding dengan kecepatan asam laktat yang terbentuk akibat beratnya aktivitas yang dilakukan.

Bal, et al. (2015) menjelaskan bahwa tingkat kinerja individu (durasi kerja dan usaha untuk melakukan pekerjaan) menentukan tingkat kenaikan asam laktat. Ahmaidi (1996) menyebutkan bahwa besarnya kadar asam laktat dalam darah sebanding dengan kadar asam laktat dalam otot seseorang. Kadar asam laktat dalam darah saat keadaan istirahat pada orang sehat berkisar antara 1-2 mmol/l (Janssen, 1987); 1,1 mmol/l (10 mg/100 ml) (Neiman, 1986); 1-1,78 mmol/1 (Mattner, 1988); 1-1,8 mmol/1 (Foxet al., 1993). 
Ambang batas asam laktat dalam kondisi normal adalah 2 mmol/1 (Tanaka et al., 1983). Kadar asam laktat darah yang melebihi ambang batas (lebih besar dari $2 \mathrm{mmol} / \mathrm{l})$ mengindikasikan terjadinya kelelahan (Mattner, 1988). Peningkatan kadar laktat lebih dari $2 \mathrm{mmol} / \mathrm{l}$ mengindikasikan telah terjadi hipoksia jaringan, sedangkan peningkatan laktat lebih dari $4 \mathrm{mmol} / \mathrm{l}$ dan tidak turun setelah resusitasi mengindikasikan telah terjadi kerusakan organ (Leksana, 2010).

Proyek Apartemen Gunawangsa Tidar Superblock di PT. PP (Persero) Tbk merupakan salah satu proyek pembangunan apartemen yang ada di Surabaya saat ini. Proyek pembangunan apartemen ini melibatkan banyak tenaga kerja konstruksi. Pekerjaan konstruksi adalah salah satu pekerjaan yang seringkali menyebabkan kelelahan kerja. Hal ini diakibatkan oleh jam kerja yang terlalu lama dan lingkungan kerja yang tidak mendukung. Pekerjaan bekisting merupakan item pekerjaan dengan volume pekerjaan terbesar di proyek Apartemen Gunawangsa Tidar Superblock. Zainullah, et al. (2012) menjelaskan bahwa bekisting dalam pekerjaan konstruksi beton artinya acuan, wadah atau cetakan (formwork) berfungsi untuk menampung baja tulangan dan beton basah yang akan dicor sesuai dengan bentuk yang diharapkan dan menjaga hingga proses pengerasannya.

Dalam melakukan pekerjaannya, pekerja bekisting bekerja lebih dari 8 jam per hari karena tidak ada sistem shift kerja. Selain itu, pekerja bekisting seringkali bekerja di bawah sengatan matahari, yaitu dimulai dari pagi hari hingga menjelang sore hari. Lama kerja dan paparan sengatan matahari ini dapat menjadi faktor penyebab terjadinya kelelahan kerja.

Kelelahan kerja dapat merugikan tenaga kerja maupun perusahaan. Salah satu resiko kelelahan kerja adalah terjadinya kecelakaan akibat kerja (Tarwaka et al., 2004). Data dari ILO menunjukkan bahwa hampir setiap tahun sebanyak dua juta pekerja meninggal dunia karena kecelakaan kerja yang disebabkan oleh faktor kelelahan. Penelitian tersebut menyatakan dari 58.155 sampel didapatkan $32,8 \%$ atau 18.828 sampel menderita kelelahan (Ahmad and Amanatun, 2015).

Kelelahan kerja adalah salah satu masalah bagi kesehatan dan keselamatan pekerja. Kelelahan kerja perlu diperhatikan secara khusus sebab pekerja merupakan aset perusahaan yang sangat menentukan keberlangsungan sebuah perusahaan. Untuk menghilangkan berbagai potensi yang dapat menimbulkan kelelahan pekerja dibutuhkan pengkajian yang lebih seksama sehingga berbagai dampak negatif yang akan timbul sedini mungkin dapat dicegah. Salah satu pengkajian tersebut dapat dilakukan dengan pengukuran kadar asam laktat dalam darah. Oleh karena itu, peneliti tertarik untuk meneliti peningkatan kadar asam laktat dalam darah sesudah bekerja (studi pada pekerja bekisting Proyek Apartemen Gunawangsa Tidar Superblock di PT. PP (Persero) Tbk.). Tujuan penelitian ini adalah mengetahui peningkatan kadar asam laktat dalam darah sesudah bekerja (Studi pada pekerja bekisting Proyek Apartemen Gunawangsa Tidar Superblock di PT. PP (Persero) Tbk.).

\section{METODE}

Penelitian ini merupakan penelitian deskriptif dengan rancang bangun cross-sectional study dimana pengamatan dan pengukuran terhadap variabel-variabel yang akan dihubungkan dilaksanakan pada saat atau periode yang sama. Ditinjau dari analisis data, penelitian ini termasuk penelitian deskriptif analitik yang ditunjang dengan pemeriksaan laboratorium terhadap sampel darah subjek penelitian. Penelitian ini termasuk penelitian lapangan apabila ditinjau dari tempat penelitiannya, dimana pengamatan dan pengukuran variabel penelitian dilakukan di lapangan atau lokasi penelitian.

Populasi dalam penelitian ini adalah semua pekerja bekisting Proyek Apartemen Gunawangsa Tidar Superblock di PT. PP (Persero) Tbk. yang berjumlah 45 orang. Sampel dalam penelitian ini adalah pekerja bekisting Proyek Apartemen Gunawangsa Tidar Superblock di PT. PP (Persero) Tbk. yang ditentukan dan diambil dengan metode simple random sampling dengan rumus sebagai berikut:

\section{$\mathrm{a}=\frac{(\mathrm{Z} 1-\mathrm{m})^{2} \mathrm{pqN}}{\left.\mathbf{d}^{2} \cdot(\mathrm{N}-1)+(\mathrm{Z} 1-\mathbf{\alpha})^{2}\right) \cdot \mathrm{p} \cdot \mathrm{q}}$}
Keterangan:
$\mathrm{n}=$ besar sampel
$\mathrm{N}=$ besar populasi
$\alpha=0,05=5 \%$
$\mathrm{P}=0,5$
$\mathrm{q}=1-\mathrm{p}$
$Z=1,96$ (tingkat kepercayaan 95\%)
$\mathrm{d}=0,11$ 
Jumlah populasi pekerja bekisting Proyek Apartemen Gunawangsa Tidar Superblock di PT. PP (Persero) Tbk. sebanyak 45 orang, maka:

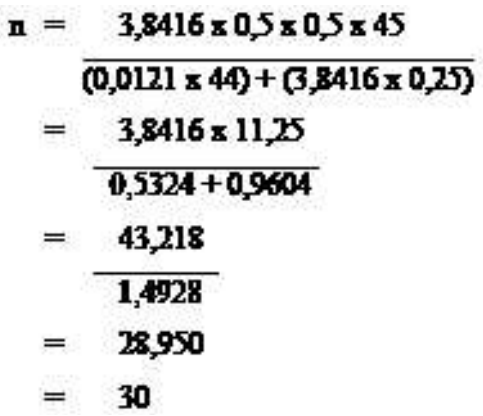

Hasil perhitungan dengan menggunakan rumus tersebut menghasilkan jumlah sampel sebanyak 30 orang. Sedangkan, lokasi pengamatan, pengambilan sampel, dan pengujian sampel darah dilakukan di Proyek Apartemen Gunawangsa Tidar Superblock PT. PP (Persero) Tbk. Waktu pengamatan, pengambilan sampel, dan pengujian sampel darah dilakukan pada periode yang sama pada Desember 2016 - Januari 2017.

Dalam penelitian ini variabel bebas adalah bekerja sedangkan variabel terikat adalah kadar asam laktat dalam darah. Pengukuran kadar asam laktat dalam darah menggunakan alat Accutrend Plus Merk Roche. Pengukuran kadar asam laktat dalam darah pekerja dilakukan sebanyak dua kali yaitu sebelum dan sesudah bekerja. Pengambilan darah dan pengukuran kadar asam laktat dalam darah dilakukan oleh tenaga laboran dari Laboratorium Ilmu Faal Kedokteran Fakultas Kedokteran Universitas Airlangga.

Pengumpulan data primer melalui wawancara dengan kuesioner serta pengujian kadar asam laktat dalam darah pekerja bekisting. Wawancara ditujukan pada responden yaitu pekerja bekisting Proyek Apartemen Gunawangsa Tidar Superblock di PT. PP (Persero) Tbk. terkait jenis kelamin, umur, masa kerja, lama waktu kerja, lama waktu istirahat, hari kerja, dan persepsi ada tidaknya paparan panas. Data sekunder diperoleh dari instansi yaitu PT. PP (Persero) Tbk. yaitu data tentang profil perusahaan,

Data yang diperoleh disajikan dalam bentuk tabel dan narasi, kemudian dianalisis secara deskriptif dengan menggunakan uji statistik, dengan $a=0,05$. Uji statistik yang digunakan adalah Wilcoxon Signed Ranks Test untuk mengetahui peningkatan kadar asam laktat darah sesudah bekerja pada pekerja bekisting Proyek Apartemen Gunawangsa Tidar Superblock di PT. PP (Persero) Tbk.

\section{HASIL}

Karakteristik Pekerja Bekisting Proyek Apartemen Gunawangsa Tidar Superblock

Pekerjaan bekisting merupakan item pekerjaan dengan volume pekerjaan terbesar di proyek Apartemen Gunawangsa Tidar Superblock yaitu mencapai $236.759 \mathrm{~m}^{2}$. Pekerjaan bekisting di proyek ini dilakukan oleh 45 pekerja yang secara keseluruhan berjenis kelamin laki-laki.

Pekerja bekisting bekerja lebih dari 8 jam per hari dimulai dari pukul 07.30 WIB sampai pukul21.30 WIB dengan jadwal istirahat 2 (dua) kali sehari yaitu pada siang hari pukul 11.30-13.00 WIB dan malam hari pukul 17.30 WIB-19.00. Hari kerja berlaku non stop setiap minggunya yaitu Senin sampai Minggu. Selain itu, pekerja bekisting seringkali bekerja di bawah sengatan matahari.

\section{Karakteristik Responden}

\section{Umur Responden}

Umur responden dikelompokkan berdasarkan hasil perhitungan statistik. Distribusi frekuensi responden berdasarkan umur dapat dilihat pada Tabel 1.

Tabel 1 menunjukkan bahwa umur responden yang terbanyak adalah kategori umur 20-24 tahun yaitu sebesar $30,0 \%$ atau sebanyak 9 orang. Paling

Tabel 1. Distribusi Responden Berdasarkan Umur Tahun 2016

\begin{tabular}{ccc}
\hline Umur (tahun) & Jumlah & Persentase (\%) \\
\hline $15-19$ & 1 & 3,3 \\
$20-24$ & 9 & 30,0 \\
$25-29$ & 4 & 13,3 \\
$30-34$ & 3 & 10,0 \\
$35-39$ & 3 & 10,0 \\
$40-44$ & 6 & 20,0 \\
$45-49$ & 2 & 6,7 \\
$50-54$ & 2 & 6,7 \\
\hline Total & 30 & 100 \\
\hline
\end{tabular}


Tabel 2. Distribusi Responden Berdasarkan Masa Kerja Tahun 2016

\begin{tabular}{ccc}
\hline Masa Kerja & Jumlah & Persentase (\%) \\
\hline$<8$ bulan & 16 & 53,3 \\
$\geq 8$ bulan & 14 & 46,7 \\
\hline Total & 30 & 100 \\
\hline
\end{tabular}

Tabel 3. Distribusi Responden Berdasarkan Persepsi Paparan Panas Tahun 2016

\begin{tabular}{ccc}
\hline $\begin{array}{c}\text { Persepsi } \\
\text { Paparan Panas }\end{array}$ & Jumlah & Persentase (\%) \\
\hline Ada & 30 & 100 \\
Tidak & 0 & 0 \\
\hline Total & 30 & 100 \\
\hline
\end{tabular}

sedikit adalah kategori umur 15-19 tahun yaitu sebesar 3,3\% atau sebanyak 1 orang.

\section{Masa Kerja Responden}

Masa kerja responden dikelompokkan berdasarkan hasil perhitungan statistik. Distribusi frekuensi responden berdasarkan masa kerja dapat dilihat pada Tabel 2. Tabel 2 menunjukkan bahwa sebagian besar responden mempunyai masa kerja $<8$ bulan ialah sebesar 53,3\% atau berjumlah 16 orang.

\section{Karakteristik Lingkungan}

Karakteristik lingkungan dinilai berdasarkan persepsi responden tentang ada tidaknya paparan panas dari sinar matahari selama melakukan pekerjaannya. Distribusi frekuensi responden berdasarkan persepsi paparan panas dapat dilihat pada tabel 3. Tabel 3, dapat diketahui bahwa keseluruhan dari responden mempunyai persepsi ada paparan panas dari sinar matahari selama melakukan pekerjaannya $(100 \%)$.

\section{Kadar Asam Laktat dalam Darah Responden Sebelum dan Sesudah Bekerja}

Kadar asam laktat dalam darah responden diukur sebanyak dua kali yaitu sebelum dan sesudah bekerja dengan menggunakan Accutrend Plus Merk Roche. Hasil pemeriksaan kadar asam laktat dalam darah responden dapat dilihat pada Tabel 4 dan Tabel 5 .
Tabel 4. Hasil Pemeriksaan Kadar Asam Laktat dalam Darah Responden Sebelum Bekerja Tahun 2016

\begin{tabular}{cc}
\hline Sampel Penelitian & $\begin{array}{c}\text { Kadar Asam Laktat } \\
\text { Dalam Darah Sebelum } \\
\text { Bekerja (mmol/I) }\end{array}$ \\
\hline Responden 1 & 1,1 \\
Responden 2 & 0,1 \\
Responden 3 & 0,1 \\
Responden 4 & 0,1 \\
Responden 5 & 0,1 \\
Responden 6 & 0,9 \\
Responden 7 & 0,1 \\
Responden 8 & 0,1 \\
Responden 9 & 0,1 \\
Responden 10 & 0,1 \\
Responden 11 & 2,3 \\
Responden 12 & 0,1 \\
Responden 13 & 1,0 \\
Responden 14 & 0,1 \\
Responden 15 & 0,1 \\
Responden 16 & 0,1 \\
Responden 17 & 0,1 \\
Responden 18 & 0,1 \\
Responden 19 & 0,1 \\
Responden 20 & 0,1 \\
Responden 21 & 0,1 \\
Responden 22 & 0,1 \\
Responden 23 & 0,1 \\
Responden 24 & 0,1 \\
Responden 25 & 0,1 \\
Responden 26 & 0,1 \\
Responden 27 & 0,1 \\
Responden 28 & 0,1 \\
Responden 29 & 0,1 \\
Responden 30 & \\
\hline & \\
\hline & \\
\hline
\end{tabular}

Tabel 4 menunjukkan bahwa rata-rata kadar asam laktat dalam darah responden sebelum bekerja yaitu $0,263 \mathrm{mmol} / 1$. Kadar asam laktat dalam darah responden sebelum bekerja yang melebihi nilai ambang batas yaitu 3,3\%. Dari uji normalitas data diperoleh $P$ value $=0,000<0,05$ sehingga dikatakan bahwa kadar asam laktat dalam darah responden sebelum bekerja tidak berdistribusi normal. 
Tabel 5 dapat diketahui bahwa rata-rata kadar asam laktat dalam darah responden sesudah bekerja yaitu $0,883 \mathrm{mmol} / 1$. Kadar asam laktat dalam darah responden sesudah bekerja yang melebihi nilai ambang batas atau lebih dari $2 \mathrm{mmol} / \mathrm{l}$ yaitu sebesar $16,7 \%$. Setelah dilakukan uji normalitas data, maka

Tabel 5. Hasil Pemeriksaan Kadar Asam Laktat Dalam Darah Responden Sesudah Bekerja Tahun 2016

\begin{tabular}{|c|c|}
\hline Sampel Penelitian & $\begin{array}{c}\text { Kadar Asam Laktat dalam } \\
\text { Darah Sesudah Bekerja } \\
(\mathrm{mmol} / \mathrm{l})\end{array}$ \\
\hline Responden 1 & 1,1 \\
\hline Responden 2 & 0,1 \\
\hline Responden 3 & 0,1 \\
\hline Responden 4 & 0,1 \\
\hline Responden 5 & 1,0 \\
\hline Responden 6 & 0,1 \\
\hline Responden 7 & 2,0 \\
\hline Responden 8 & 1,4 \\
\hline Responden 9 & 1,0 \\
\hline Responden 10 & 2,3 \\
\hline Responden 11 & 2,1 \\
\hline Responden 12 & 0,1 \\
\hline Responden 13 & 0,1 \\
\hline Responden 14 & 1,0 \\
\hline Responden 15 & 2,1 \\
\hline Responden 16 & 0,1 \\
\hline Responden 17 & 1,0 \\
\hline Responden 18 & 0,9 \\
\hline Responden 19 & 0,1 \\
\hline Responden 20 & 0,1 \\
\hline Responden 21 & 2,3 \\
\hline Responden 22 & 1,0 \\
\hline Responden 23 & 0,1 \\
\hline Responden 24 & 0,1 \\
\hline Responden 25 & 1,0 \\
\hline Responden 26 & 1,0 \\
\hline Responden 27 & 2,1 \\
\hline Responden 28 & 0,1 \\
\hline Responden 29 & 1,0 \\
\hline Responden 30 & 1,0 \\
\hline
\end{tabular}

diperoleh $P$ value $=0,057>0,05$ sehingga dikatakan bahwa kadar asam laktat dalam darah responden sesudah bekerja berdistribusi normal.

Uji statistik Wilcoxon Signed Ranks Test yang telah dilakukan menunjukkan hasil nilai $\mathrm{N}$ Negative Ranks $=3, \mathrm{~N}$ Positive Ranks $=16, \mathrm{~N}$ Ties $=11$ dengan Asymp. Sig. (2-tailed) $=0,001$. N Negative Ranks $=3$ berarti bahwa jumlah responden dengan kadar asam laktat dalam darah sesudah bekerja lebih kecil dari kadar asam laktat dalam darah sebelum bekerja yaitu 3 orang. $\mathrm{N}$ Positive Ranks $=16$ berarti bahwa responden dengan kadar asam laktat dalam darah sesudah bekerja lebih besar dari kadar asam laktat dalam darah sebelum bekerja yaitu 16 orang. $\mathrm{N}$ Ties $=11$ berarti bahwa jumlah responden dengan kadar asam laktat dalam darah sesudah bekerja sama dengan kadar asam laktat dalam darah sebelum bekerja yaitu 11 orang.

\section{PEMBAHASAN}

\section{Karakteristik Responden}

\section{Jenis Kelamin Responden}

Semua responden adalah laki-laki yang berjumlah 30 orang. Suma'mur (1996) dan Tarwaka, et al. (2004) mengemukakan bahwa laki-laki mempunyai ukuran tubuh dan kekuatan relatif lebih besar dibanding wanita. Wanita lebih teliti dibandingkan laki-laki dalam melakukan pekerjaan tertentu, namun kekuatan fisik wanita hanya $2 / 3$ dari kemampuan fisik atau kekuatan otot laki-laki. Laki-laki tidak mengalami haid, kehamilan, dan menopause sehingga laki-laki tidak mempunyai kecenderungan mudah mengalami kelelahan seperti pada wanita.

Tarwaka, et al. (2004) juga mengemukakan bahwa laki-laki mempunyai maksimum tenaga aerobik sedikit lebih tinggi dibanding wanita yaitu 3,0 L/menit. $\mathrm{VO}_{2} \max$ laki-laki lebih tinggi dibandingkan dengan wanita, $\mathrm{VO}_{2} \max$ wanita 15-30\% lebih rendah dari laki-laki. Hal tersebut menyebabkan persentase lemak tubuh laki-laki lebih rendah dan kadar $\mathrm{Hb}$ darah lebih tinggi daripada wanita. Hemoglobin berfungsi membawa oksigen dari paru-paru ke jaringan (Roger, 2002). Keseluruhan responden yang berjenis kelamin laki-laki tidak mempunyai kecenderungan mudah mengalami kelelahan kerja otot seperti pada wanita karena kadar $\mathrm{Hb}$ darah pada laki-laki yang lebih 
tinggi daripada wanita akan menyebabkan pasokan oksigen ke jaringan otot pada laki-laki juga lebih banyak daripada wanita.

\section{Umur Responden}

Hasil wawancara menggunakan kuesioner memperoleh hasil bahwa sebagian besar responden berumur 20-24 yaitu sebesar 30,0\%. Tarwaka, et al. (2004) menyatakan bahwa umur seseorang berhubungan dengan kapasitas fisik dimana kekuatannya terus bertambah sampai batas tertentu dan mencapai puncaknya pada umur 25 tahun. Pada umur 50-60 tahun terjadi berbagai penurunan kemampuan tubuh, kekuatan otot menurun sebesar $25 \%$ dan kemampuan sensoris-motoris menurun sebanyak $60 \%$. Umur seseorang yang telah melebihi 60 tahun, maka kemampuan kerja fisik seseorang tersebut hanya tersisa $50 \%$ dari umur orang yang berumur 25 tahun.

Bertambahnya umur setelah seseorang mencapai puncak kekuatan fisik (25 tahun) akan diikuti penurunan $\mathrm{VO}_{2}$ max, tajam penglihatan, pendengaran, kecepatan membedakan sesuatu, membuat keputusan, dan kemampuan mengingat jangka pendek. Pangestu (2014) juga mengemukakan bahwa tingkat konsumsi oksigen maksimal $\left(\mathrm{VO}_{2} \max \right)$ yang dimiliki oleh seseorang berhubungan dengan metabolisme senyawa penyebab kelelahan pada tubuhnya yaitu asam laktat. Tingkat konsumsi oksigen maksimal $\left(\mathrm{VO}_{2}\right.$ max $)$ yang tinggi mampu membantu proses penurunan kadar asam laktat darah dengan cepat, begitu pula sebaliknya bahwa tingkat konsumsi oksigen maksimal $\left(\mathrm{VO}_{2}\right.$ max $)$ yang rendah mampu membantu proses penurunan kadar asam laktat darah dengan lambat. Dengan demikian dapat dikatakan bahwa sebagian besar responden termasuk ke dalam usia pertumbuhan kapasitas fisik seseorang dan mempunyai tingkat konsumsi oksigen maksimal $\left(\mathrm{VO}_{2}\right.$ max $)$ yang tinggi sehingga tubuhnya mampu membantu proses penurunan kadar asam laktat darah dengan cepat.

\section{Masa Kerja Responden}

Sebagian besar responden mempunyai masa kerja $<8$ bulan $(53,3 \%)$. Setyawati $(2010)$ menyatakan apabila seseorang yang bekerja dengan masa kerja yang lama akan lebih banyak memiliki pengalaman dibandingkan dengan seseorang yang bekerja dengan masa kerja yang tidak terlalu lama. Orang yang bekerja lama sudah terbiasa dengan pekerjaan yang dilakukannya sehingga tidak menimbulkan kelelahan kerja bagi dirinya. Oleh karena itu, hasil penelitian ini menunjukkan bahwa sebagian besar responden yang mempunyai masa kerja $<8$ bulan memiliki kecenderungan lebih mudah mengalami kelelahan dibandingkan dengan sebagian kecil responden yang mempunyai masa kerja $>8$ bulan.

\section{Karakteristik Organisasi}

Seluruh responden bekerja selama 11 jam/hari, 7 hari/minggu, dan mempunyai waktu istirahat selama $3 \mathrm{jam} / \mathrm{hari}$ yang terbagi menjadi dua sesi masingmasing selama 1,5 jam/sesi. Undang-Undang No. 3 Tahun 2003 Tentang Ketenagakerjaan Pasal 77 Ayat (1), berbunyi bahwa setiap pengusaha wajib melaksanakan ketentuan waktu kerja. Waktu kerja sebagaimana dimaksud dalam ayat (1) meliputi:

1) 7 (tujuh) jam 1 (satu) hari dan 40 (empat puluh) jam 1 (satu) minggu untuk 6 (enam) hari kerja dalam 1 (satu) minggu; atau 2) 8 (delapan) jam 1 (satu) hari dan 40 (empat puluh) jam 1 (satu) minggu untuk 5 (lima) hari kerja dalam 1 (satu) minggu.

Lama kerja dan hari kerja responden dalam penelitian tidak sesuai dengan Undang-Undang No. 13 Tahun 2003 Tentang Ketenagakerjaan. Wignjosoebroto (2008) menjelaskan bahwa jam kerja harian yang diperpanjang dengan kerja lembur yang berlebihan tidak hanya memberikan hasil kerja yang akan meragukan, tetapi juga akan diikuti dengan meningkatnya absen karena sakit atas rasa lelah yang berlebihan yang dialami oleh pekerja. Pengaturan jadwal kerja harian sebesar 8 jam per hari sudah merupakan hasil yang optimal dan sulit untuk dilampaui tanpa menimbulkan dampak buruk terhadap fisik pekerja. Perpanjangan waktu kerja harian lebih dari 8 jam dengan kerja lembur hanya akan menurunkan efisiensi kerja, meningkatkan kelelahan, kecelakaan, dan penyakit akibat kerja (Tarwaka et al., 2004).

Tarwaka, et al, (2004) berpendapat bahwa di antara waktu kerja harian harus disediakan waktu istirahat yang jumlahnya berkisar antara 15-30\% dari seluruh waktu kerja. Hasil penelitian yang dilakukan menunjukkan bahwa responden bekerja selama $11 \mathrm{jam} /$ hari sehingga waktu istirahat yang harus disediakan bagi responden sekitar 99 menit/ hari (1,65 jam/hari) sampai 198 menit/hari (3,3 jam/ hari). Dengan demikian, lama waktu istirahat yang disediakan bagi responden dapat dikatakan cukup untuk memulihkan keadaannya atau melanjutkan pekerjaannya lagi. 


\section{Karakteristik Lingkungan}

Hasil penelitian menunjukkan bahwa keseluruhan dari responden $(100 \%)$ mempunyai persepsi ada paparan panas dari sinar matahari selama melakukan pekerjaannya. Hal ini menunjukkan bahwa keseluruhan dari responden mengalami tekanan panas dalam melakukan pekerjaannya. Tarwaka, et al. (2004) mengemukakan apabila suatu lingkungan kerja memiliki tekanan panas maka memerlukan upaya tambahan pada anggota tubuh manusia untuk memelihara keseimbangan panas. Risiko terjadinya gangguan kesehatan juga akan meningkat apabila paparan tekanan panas secara terus menerus. Salah satu gangguan kesehatan tersebut meliputi gangguan performasi kerja berupa kelelahan.

Soedirman dan Suma'mur (2014) juga mengemukakan bahwa pengaruh suhu yang tinggi akan mengakibatkan heat exhaustion (kelelahan panas) yang dapat terjadi pada keadaan dehidrasi atau defisiensi garam tanpa dehidrasi. Kelainan ini dapat dipercepat terjadinya pada orang yang kurang minum, berkeringat banyak, muntah, diare atau penyebab lain yang mengakibatkan pengeluaran air berlebihan sehingga mudah terjadi kelelahan. Kelelahan akibat panas, terjadi karena cuaca kerja yang sangat panas, terutama tenaga kerja yang belum teraklimatisasi.

\section{Kadar Asam Laktat dalam Darah Responden Sebelum Bekerja}

Hasil penelitian yang dilakukan menunjukkan bahwa kadar asam laktat dalam darah responden sebelum bekerja berada pada rentang 0,1-2,3 mmol/1. Rata-rata kadar asam laktat dalam darah responden sebelum bekerja yaitu 0,263 $\mathrm{mmol} / 1$. Kadar asam laktat dalam darah responden sebelum bekerja yang ditemukan dalam penelitian ini tidak jauh berbeda dengan teori yang dikemukakan oleh Janssen (1987) yaitu kadar asam laktat dalam darah saat keadaan istirahat pada orang sehat berkisar antara $1-2 \mathrm{mmol} / \mathrm{l}$.

Tanaka, et al. (1983) menyebutkan bahwa ambang batas asam laktat dalam kondisi normal adalah $2 \mathrm{mmol} / \mathrm{l}$. Kadar asam laktat darah yang melebihi nilai ambang batas (lebih besar dari $2 \mathrm{mmol} / \mathrm{l}$ ) mengindikasikan adanya kelelahan (Mattner, 1988). Hal ini menunjukkan bahwa kondisi awal sebagian besar responden sebelum bekerja dalam kondisi normal atau tidak lelah. Hasil penelitian juga diketahui terdapat sebagian kecil responden sebesar $(3,3 \%)$ mengalami kelelahan sebelum bekerja.

Suma'mur (2009) menyatakan jika tenaga kerja telah mulai merasa lelah dan tetap dipaksa untuk terus bekerja, maka kondisi kelelahan akan semakin bertambah parah dan kondisi tersebut pada akhirnya akan sangat mengganggu kelancaran pekerjaan dan berdampak buruk terhadap tenaga kerja yang bersangkutan. Pekerja yang mengalami kelelahan perlu melakukan upaya pemulihan untuk mengembalikan keadaannya menjadi normal. Istirahat sebagai upaya pemulihan dapat dilakukan dengan berhenti bekerja yang bervariasi dari istirahat sewaktu-waktu dalam waktu sangat pendek sebentar saja sampai dengan tidur malam hari atau cuti panjang dari pekerjaan. Oleh karena itu, sebagian responden yang mengalami kelelahan sebelum bekerja seharusnya tidak memutuskan untuk memulai pekerjaannya, akan tetapi mengambil kesempatan untuk beristirahat yang dapat dilakukan dengan tidur atau cuti dari pekerjaan.

\section{Kadar Asam Laktat dalam Darah Responden Sesudah Bekerja}

Hasil penelitian yang telah dilakukan menunjukkan bahwa kadar asam laktat dalam darah responden sesudah bekerja berada pada rentang $0,1-$ $2,3 \mathrm{mmol} / \mathrm{l}$. Rata-rata kadar asam laktat dalam darah responden sesudah bekerja yaitu $0,883 \mathrm{mmol} / \mathrm{l}$. Hal ini menunjukkan bahwa kondisi sebagian besar responden sesudah bekerja dalam kondisi normal atau tidak lelah. Hasil penelitian juga menunjukkan bahwa kadar asam laktat dalam darah sesudah bekerja pada sebagian kecil responden $(16,7 \%)$ mengindikasikan terjadinya kelelahan (melebihi nilai ambang batas $2 \mathrm{mmol} / \mathrm{l})$. Hal ini sesuai dengan teori yang dikemukakan oleh Murray (2005) yaitu tubuh manusia akan menerima rangsangan selama melakukan pekerjaannya, yang menyebabkan otot berkontraksi secara terus menerus sehingga suplai oksigen ke otot akan berkurang. Kondisi ini mengakibatkan terjadinya pergeseran sumber energi aktivitas otot yang semula berasal dari asam lemak ketika suplai oksigen cukup, kemudian beralih ke sumber energi lain yang proses perombakannya tidak memerlukan oksigen. Sumber energi aktivitas otot saat ketersediaan oksigen tidak cukup berupa karbohidrat yaitu glukosa (Matthew, 2003). Glukosa akan diubah menjadi asam piruvat melalui reaksi glikolisis anaerobik. Asam piruvat akan mengalami reduksi menjadi asam laktat. Asam laktat bersifat 
sangat merugikan karena dapat menyebabkan kelelahan kerja otot (Murray, 2005).

Ardle, et al. (1981) dan Fox, et al. (1993) berpendapat bahwa asam laktat yang terbentuk dari glikolisis anaerobik akan menurunkan $\mathrm{pH}$ sehingga suasana otot berubah menjadi asam. Keadaan ini dapat meningkatkan keasaman darah apabila berlangsung lama. Perubahan $\mathrm{pH}$ dalam otot yang menjadi asam ini akan menghambat kerja enzim-enzim glikolisis sehingga akan mengganggu reaksi kimia yang berlangsung di dalam sel. Hal ini akan mengakibatkan berkurangnya energi yang dihasilkan sehingga kontraksi otot semakin lemah dan pada akhirnya otot akan mengalami kelelahan.

Kelelahan yang terjadi pada responden setelah bekerja harus ditanggulangi agar tidak berkembang menjadi kelelahan kronis. Upaya penanggulangan kelelahan yang dilakukan salah satunya dengan cara istirahat sebagai pemulihan. Hal ini sesuai dengan teori yang dikemukakan oleh Janssen (1987) dimana istirahat merupakan upaya pemulihan yang dapat membersihkan atau mengeliminasi asam laktat dari tubuh. Selain itu, Brooks (1986) dan Peterson (2006) juga mengemukakan bahwa proses penting dalam pemulihan kadar asam laktat darah adalah terjadinya oksidasi asam laktat menjadi asam piruvat kembali oleh sel didalam jaringan otot atau di limpa dan hati. Istirahat memegang peranan penting dalam upaya menanggulangi kelelahan yang dialami sebagian kecil responden karena dengan istirahat tubuh mempunyai kesempatan untuk mendapatkan pasokan oksigen sehingga mampu mengoksidasi asam laktat menjadi asam piruvat kembali.

Pemulihan kadar asam laktat darah dapat berlangsung secara aktif maupun pasif (Janssen, 1987). Afriwardi dan Rezki (2008) menjelaskan bahwa tahap pemulihan aktif terjadi bila penghentian aktivitas atau latihan terjadi secara perlahan-lahan dengan mengurangi baik kuantitas maupun kualitas aktivitas sampai pada keadaan hasil metabolit berada pada tingkat normal. Pemulihan dikatakan pasif apabila aktivitas dihentikan segera tanpa melalui tahap pengurangan kualitas maupun kuantitas aktivitas. Tahap pemulihan yang dilakukan mempengaruhi kemampuan tubuh dalam mengeliminasi bahan metabolit, termasuk asam laktat. Salah satu pemulihan kadar asam laktat darah secara aktif yang dapat dilakukan responden yaitu dengan cara melakukan peregangan otot atau duduk sejenak di antara waktu kerja, sedangkan pemulihan kadar asam laktat darah secara pasif dapat dilakukan responden dengan cara tidur meninggalkan pekerjaan.

\section{Peningkatan Kadar Asam Laktat dalam Darah Responden Sesudah Bekerja}

Uji statistik Wilcoxon Signed Ranks Test yang dilakukan memperoleh hasil $\mathrm{N}$ Negative Ranks $=3, \mathrm{~N}$ Positive Ranks $=16, \mathrm{~N}$ Ties $=11$ dengan Asymp. Sig. $(2$-tailed $)=0,001$. N Ties $=11$ berarti bahwa jumlah responden dengan kadar asam laktat dalam darah sesudah bekerja sama dengan kadar asam laktat dalam darah sebelum bekerja yaitu sebanyak 11 orang. Hal ini sesuai dengan teori yang dikemukakan oleh Leksana (2010), dimana pada kondisi normal terdapat keseimbangan antara produksi laktat dan pembersihan laktat. Laju produksi asam laktat akibat dari aktivitas kerja yang dilakukan oleh responden seimbang dengan laju pembersihan asam laktat yang dilakukan oleh tubuh responden. Seperti yang diketahui bahwa pembersihan asam laktat dapat terjadi dengan upaya pemulihan baik secara aktif maupun pasif yang dilakukan oleh responden.

$\mathrm{N}$ Positive Ranks $=16$ berarti bahwa jumlah responden dengan kadar asam laktat dalam darah sesudah bekerja lebih besar dari kadar asam laktat dalam darah sebelum bekerja yaitu sebanyak 16 orang. Janssen (1987) menyebutkan bahwa peningkatan kadar asam laktat disebabkan oleh aktivitas kerja yang bersifat intensif dan berulangulang serta tidak disertai dengan waktu pemulihan yang cukup sehingga akan menghambat pasokan energi dari sistem enzim aerobik pada sel otot. Hal ini menunjukkan bahwa mekanisme yang terjadi pada tubuh responden tidak berjalan normal yaitu tidak ada keseimbangan antara laju produksi asam laktat akibat aktivitas kerja dengan laju pembersihan asam laktat yang didapatkan melalui pemulihan, laju produksi laktat lebih besar dibandingkan dengan laju pembersihan asam laktat.

$\mathrm{N}$ Negative Ranks $=3$ berarti bahwa jumlah responden dengan kadar asam laktat dalam darah sesudah bekerja lebih kecil dari kadar asam laktat dalam darah sebelum bekerja yaitu 3 orang. Fox, et al (1993) berpendapat bahwa pada aktivitas fisik yang semakin tinggi akan menyebabkan terjadinya pergeseran pasokan energi yang semula dari sistem energi aerobik bergeser ke sistem energi anaerobik sehingga dapat meningkatkan kadar asam 
laktat darah. Penemuan kadar asam laktat dalam darah sesudah bekerja lebih kecil dari kadar asam laktat dalam darah sebelum bekerja menggambarkan bahwa aktivitas fisik yang dilakukan responden selama bekerja lebih rendah dibandingkan aktivitas fisik sebelum bekerja.

\section{SIMPULAN}

Hasil analisis yang telah dilakukan terhadap kadar asam laktat dalam darah sebelum dan sesudah bekerja pada pekerja bekisting Proyek Apartemen Gunawangsa Tidar Superblock di PT. PP (Persero) Tbk. Menunjukkan kesimpulan bahwa terdapat peningkatan kadar asam laktat dalam darah sesudah bekerja dengan diperoleh $\mathrm{N}$ Positive Ranks $=16$ dengan Asymp. Sig. (2-tailed $)=0.001$.

\section{DAFTAR PUSTAKA}

Afriwardi., Rezki, W.R., 2008. Pengaruh Pemulihan Aktif dan Pemulihan Pasif Terhadap Lamanya Perubahan Kadar Laktat Darah Pada Mahasiswa Fakultas Kedokteran Universitas Andalas. Majalah Kedokteran Andalas, 32(2): pp. 190-197.

Ahmad, S., Amanatun, A., 2015. Beban Kerja dengan Kelelahan Kerja Pada Pekerja Industri Keripik Melinjodi Desa Benda Indramayu. Jurnal Kesehatan masyarakat, 1(3): pp. 25-30.

Ahmaidi, S., 1996. Effect of Active Recovery on Plasma Lactate and Anaerobic Power Following Repeated Intensive Exercise. Med Sci Sport Exerc, 2(4): pp. 450-456.

Ardle, W.D.M., Katch, F.I., and Katch, V.L., 1981. Exercise Physiology, Energy, Nutrition, and Human Performance. Philadelphia: Lea \& Febinger.

Bal, E., Arslan, O., and Leyla T., 2015. Prioritization of The Causal Factors of Fatigue in Seafarers and Measurement of Fatigue with The Application of The Lactate Test. Safety Science, 72: pp. 46-54.

Brooks, G.A., 1986. The Lactate Shuttle During Exercise and Recovery. Medicine and Science in Sport Exercise, 18(3): pp. 360-367.

Farenia, R., Lesmana, R., Purba, A., dan Akbar, L.B., 2010. Perbandingan antara Kadar Serum Mioglobin dengan Laktat Setelah Aktivitas Fisik Aerobik dan Anaerobik Pada Tikus Wistar. Bandung: Universitas Padjajaran.
Fox, E.L., Bowers, R.W., and Foss, M.L., 1993. The Physiological Basis of Exercise and Sport. Dubuque: Wm. C. Communication Inc.

Janssen, P.J.M., 1987. Training Lactate Pulse Rate. Oulu Finland: Polar Electro Oy Pub.

Lamb, D.R., 1984. Physiology of Exercise Responses and Adaptation. New York: MacMillan Publishing Co. Inc.

Leksana, E., 2010. Kadar Laktat sebagai Parameter Resusitasi. Cermin Dunia Kedokteran, 37(7): pp. 545-548.

Matthew, W.J., 2003. Biochemistry. Philadelphia: William \& Wilkins Co.

Mattner, U., 1988. Lactate in Sport Medicine. Germany: Boehringer Mannheim GmbH.

Murray, J.W., 2005. Biokimia Harper. Jakarta: Penerbit EGC.

Neiman, D.C., 1986. The Sport Medicine Fitness Course. California: Bull Publishing Co.

Ningrum, D.A., 2012. Perbandingan Metode Hydrotheraphy Massage dan Massage Manual Terhadap Pemulihan Kelelahan Pasca Olahraga Anaerobic Lactacid. Skripsi. Jakarta: Universitas Pendidikan Indonesia.

Pangestu, R.P., 2014. Analisis Konsumsi Oksigen Maksimal $\left(\mathrm{VO}_{2}\right.$ Max $)$ terhadap Pemulihan Kadar Asam Laktat Darah. Jurnal Kesehatan Olahraga, 2(2): pp.89-95.

Pate, R.R., Clenaghan, B.M., and Rotela, R., 1984. Scientific Foundation of Coaching. Philadelphia: Saunders College Publishing.

Peterson, L.D., 2006. Sport Injuries. London: Martin Dunitz Ltd.

Roger, W., 2002. Anatomi dan Fisiologi untuk Perawat. Jakarta: Perpustakaan Nasional.

Saltin, B.J, and Edstrom, L., 1981. Effect of Lactic Acid Accumulation and ATP Decrease on Muscle Tension and Relaxation. Am. J. Physiol, 240: pp. 121-126.

Setyawati, L., 2010. Selintas tentang Kelelahan Kerja. Yogyakarta: Amara Books.

Soedirman, dan Suma'mur., 2014. Kesehatan Kerja dalam Perspektif Hiperkes dan Keselamatan Kerja. Magelang: Erlangga.

Suma'mur, P.K., 1996. Higiene Perusahaan dan Kesehatan Kerja. Jakarta: PT. Toko Gunung Agung.

Suma'mur, P.K., 2009. Higiene Perusahaan dan Kesehatan Kerja. Jakarta: PT Toko Gunung Agung. 
Susetyo, J., Oesman, T.I., and Sudharman, S.T., 2012. Pengaruh Shift Kerja Terhadap Kelelahan Karyawan dengan Metode Bourdon Wiersma dan 30 Items of Rating Scale. Jurnal Teknologi, 5(1): pp. 32-39.

Tanaka, K., Matsuura, Y., Kumagai, S., Matsuzaka, A., Hirakoba, K., and Asano, K., 1983. Relationships of Anaerobic Threshold and Onset of Blood Lactate Accumulation with Endurance Performance. Eur. J. Appl. Physiol Occup Physiol, 52(1): pp.51-56.

Tarwaka, Solichul, H.A., Bakri, and Sudiajeng, L., 2004. Ergonomi untuk Keselamatan, Kesehatan Kerja, dan Produktivitas. Surakarta: UNIBA Press.
Undang-Undang Republik Indonesia No. 13 Tahun 2003 Tentang Ketenagakerjaan. Jakarta: Kementerian Tenaga Kerja dan Transmigrasi. Weihrer, S.J., 1991. Changes in Blood Lactate Concentration During Active Recovery at Sublactate Threshold, Lactate Threshold, and Supralactate Threshold Exercise Intensities. Thesis. Ottawa: The University.

Wignjosoebroto, S., 2008. Ergonomi Studi Gerak dan Waktu. Surabaya: Guna Widya.

Zainulah, A., Suharyanto, A., dan Budio, S.P., 2012. Pengaruh Upah, Kemampuan dan Pengalaman Kerja Terhadap Kinerja Pekerja Pelaksanaan Bekisting Pada Pekerjaan Beton. Jurnal Rekayasa Sipil, 6(2): pp. 125-133. 